\title{
A Study on the Relation between Junior High School Students' Extracurricular Reading Attitude and Learning-Associated Well-Being
}

\author{
Chin-Chang Wu, Ming-Shang Su, Ta-Chun Chang, and Chin-Wen Liao
}

\begin{abstract}
The objective of the study is to explore the association between junior high school students' extracurricular reading attitude and their learning-associated well-being. The study subjects were students at public junior high schools in Changhua County. Stratified random cluster sampling was adopted to sample 45 classes of 15 schools be the questionnaire survey subjects.

Statistical software SPSS 20.0 was used to analyze the collected data. The following conclusions were drawn.

Junior high school students in Changhua County showed a more active attitude on the reading preference aspect of extracurricular reading attitude.

Junior high school students in Changhua County showed better learning-associated well-being in terms of positive affection and physical and mental health.

Female students studying at schools in town that schedule morning reading at least three times a week, and having language contest participating experience showed a more active reading attitude.
\end{abstract}

Index Terms-Junior high school students, extra-curricular reading materials, reading attitude, learning-associated well-being.

\section{INTRODUCTION}

\section{A. Research Background and Motivation}

International communities have already recognized the importance of reading early on and been fully engaged in promoting reading. In 1956, International Reading Association (IRA) was officially established and the goal is to improve reading education, both qualitatively and quantitatively, via research. IRA has also held various conventions and released journals to make itself an organization for reading researchers to exchange and disseminate information. The ultimate goal of the association is to elevate the average reading and writing level of people worldwide and to encourage people to develop a lifelong reading habit (Tseng and Han, 2002) [1].

When planning the direction of the 12-year compulsory education, the government of Changhua County put reading as one of the key development areas for adaptive learning and considered reading competence critical for children's lifelong learning. Changhua County government also developed the

Manuscript received April 18, 2015; accepted June 24, 2015.

The authors are with the Department of Industrial Education and Technology, National Changhua University of Education, Changhua, Taiwan (e-mail: wsh1102@yahoo.com.tw, zacd1234@yahoo.com.tw, jackncue@gmail.com, tcwliao@cc.ncue.edu.tw). project "Structuring a Solid Learning Scaffolding for Children Using Learning Competence" and listed a budget for purchasing books for school libraries to enrich their library collections and improve the reading environment. The government also set up a community reading center at each school for a total of 100 schools to create a good reading environment. Both the Ministry of Education and Changhua City government have put substantial resources into the reading domain and worked on introducing students to read books other than their textbooks and to get closer to extracurricular reading materials naturally. It is useful to find out if students' attitude toward extracurricular reading materials is improved by these measures mentioned above, and therefore, the investigator conducted this study to find out the current attitude of junior high school students in Changhua County toward extracurricular reading materials. This is one of the research motivation of the present study.

Taiwanese students have always viewed reading as part of their homework rather than their interest. In fact, the percentage of Taiwanese students who read for interest is lower than the average worldwide (Ko, 2009) [2]. With the implementation of the 12-year compulsory education in August, 2014, the arrival of examination-free school admission signifies the removal of the examination burden from students. As the education policy changes, education concepts also become more pluralistic. For example, reading in recent years has become an activity promoted among all levels of schools by an all-out effort, and in this movement, extracurricular reading materials are definitely an important focus. Because grade 7, 8 and 9 students in 2013 are also students of the first three years of the 12-year compulsory education, the investigator would like to use the study to explore current junior high school students' learning-associated well-being. This is the second research motivation of the study.

Researchers have observed on the teaching site that because schools are carrying out reading related activities according to requests from the government, teachers have spent more time leading students to read extracurricular reading materials. As for parents, they also view extracurricular reading materials with a more open attitude. The investigator has made the following conclusions based findings from reviewing reading attitude related studies. First, female students tend to show a better reading attitude than male students do. Second, lower and middle grades elementary school students showed a significantly better reading attitude than higher grades elementary school students, but no relevant study on junior high school students 
is available. Third, students who enjoy reading were found to be from families with a high socioeconomic status. Fourth, the location of the school has an impact on students' reading attitude. Fifth, there are positive associations between reading attitude and reading time, reading environment at home, and support from teachers on reading. Therefore, the investigator would like to use the present study to examine if students' extracurricular reading attitude is affected by personal background variables and family and school factors. This is third research motivation of the study.

Regarding the definition of well-being, it is defined as a positive affection reflecting how happy an individual is about his or her life (Veenhovn, 1994) [3]. Buss (2000) pointed out that well-being is an on-going feeling related to realizing personal goals, leading a meaningful life, and feeling pleasant either at the very moment or about life in general [4].

As a junior high school teacher, the investigator has found that junior high school students nowadays indeed have more opportunity to get their hands on extracurricular reading materials. It is because the 12-year compulsory education prompts students to extend learning from textbooks to extracurricular reading. Reading not only improve students' academic performance and reduce stress from life but also give them knowledge for problem-solving and make them more confident about themselves. The investigator is questioning whether these impacts from reading can help students generate a positive affection in school life. That is, will reading make students happier in learning? To explore this area, the investigator used the study to examine if students' extracurricular reading attitude is correlated with the learning-associated well-being, and this is the fourth research motivation of the study.

\section{B. Research Objectives}

According to the above-mentioned research background and motivation, the investigator chose the following research objectives for this study.

1) Explore the present status of junior high school students' extracurricular reading attitude and their learning-associated well-being.

2) Analyze effects of various background variables on junior high school students' extracurricular reading attitude.

3) Analyze effects of various background variables on junior high school students' learning-associated well-being.

4) Explore the correlation between junior high school students' extracurricular reading attitude and their learning-associated well-being.

\section{RESEARCH DESIGN AND IMPLEMENTATION}

The research design and implementation of this study is presented in four sections: research framework, research subjects, research tools, and research implementation. They are described separately below.

\section{A. Research Framework}

The research framework was structured based on the research objectives and the literature review (see Fig. 1).

\begin{tabular}{|c|c|c|}
\hline \multirow{2}{*}{ Independentvariables } & \multirow[b]{3}{*}{$\mathrm{H}_{01}$} & Dependent variables \\
\hline & & Reading attitude \\
\hline \multirow{3}{*}{$\begin{array}{l}\text { 1. Gender } \\
\text { 2. Grade year } \\
\text { 3.Family socioeconomic } \\
\text { status }\end{array}$} & & 1. Reading preference \\
\hline & & 2. Reading achievement \\
\hline & & $\begin{array}{l}\text { and challenges } \\
\text { 3. Reading behavior }\end{array}$ \\
\hline $\begin{array}{l}\text { 4. Contest participation } \\
\text { experience }\end{array}$ & & $\mathrm{H}_{03} \hat{I}$ \\
\hline $\begin{array}{l}\text { 5. School location } \\
\text { 6. Weekly extracurricular } \\
\text { readingtime }\end{array}$ & & $\begin{array}{l}\text { Sense of learning happines } \\
\text { 1. Satisfaction with life }\end{array}$ \\
\hline 7. Encouragement to read & & 2. Self-approval \\
\hline from teachers & $\overline{\mathrm{H}_{0}}$ & 3. Positive affection \\
\hline $\begin{array}{l}\text { 8. Reading environment at } \\
\text { home }\end{array}$ & & $\begin{array}{l}\text { 4. Physical and mental health } \\
\text { 5. Harmonious interpersonal } \\
\text { relationship }\end{array}$ \\
\hline
\end{tabular}

Fig. 1. Research framework.

\section{B. Research Subjects}

The study subjects were public junior high school students at grades 7, 8 and 9 in Changhua County in 2013, but students from special education classes were excluded in this study (see Table I).

TABLE I: NUMBER OF JUNIOR HigH SCHOOLS IN CHANGHUA COUNTY AT PRESENT AND THE SAMPLING RATIO

\begin{tabular}{|c|c|c|c|c|}
\hline School location & Township & Town & $\begin{array}{c}\text { County- } \\
\text { administere } \\
\text { d city }\end{array}$ & Total \\
\hline $\begin{array}{c}\text { Number of } \\
\text { schools at } \\
\text { present }\end{array}$ & 20 & 14 & 7 & 41 \\
\hline $\begin{array}{c}\text { Sampling ratio } \\
(\%)\end{array}$ & $46 \%$ & $35 \%$ & $19 \%$ & $100 \%$ \\
\hline $\begin{array}{l}\text { Number of } \\
\text { schools } \\
\text { sampled }\end{array}$ & 7 & 5 & 3 & 15 \\
\hline \multirow[t]{7}{*}{$\begin{array}{l}\text { Sampled } \\
\text { schools }\end{array}$} & $\begin{array}{c}\text { Puyen } \\
\text { Junior High } \\
\text { School }\end{array}$ & $\begin{array}{c}\text { Tianzhong } \\
\text { Senior High } \\
\text { School } \\
\text { Affiliated } \\
\text { Junior High } \\
\text { School }\end{array}$ & $\begin{array}{c}\text { Changan } \\
\text { Junior High } \\
\text { School }\end{array}$ & \\
\hline & $\begin{array}{c}\text { Puxin } \\
\text { Junior High } \\
\text { School }\end{array}$ & $\begin{array}{c}\text { Lukang } \\
\text { Junior High } \\
\text { School }\end{array}$ & $\begin{array}{c}\text { Changtai } \\
\text { Junior High } \\
\text { School }\end{array}$ & \\
\hline & $\begin{array}{c}\text { HsiuShui } \\
\text { Junior High } \\
\text { School }\end{array}$ & $\begin{array}{l}\text { Sihu Junior } \\
\text { High School }\end{array}$ & $\begin{array}{c}\text { Chang-sing } \\
\text { Junior High } \\
\text { School }\end{array}$ & \\
\hline & $\begin{array}{c}\text { Shen-gang } \\
\text { Junior High } \\
\text { School }\end{array}$ & $\begin{array}{c}\text { Homei Junior } \\
\text { High School }\end{array}$ & & \\
\hline & $\begin{array}{c}\text { Dacun } \\
\text { Junior High } \\
\text { School }\end{array}$ & $\begin{array}{c}\text { Datung Junior } \\
\text { High School }\end{array}$ & & \\
\hline & $\begin{array}{c}\text { Huatan } \\
\text { Junior High } \\
\text { School }\end{array}$ & & & \\
\hline & $\begin{array}{c}\text { She-tou } \\
\text { Junior High } \\
\text { School }\end{array}$ & & & \\
\hline
\end{tabular}

\section{Research Tool}

The study adopted the questionnaire survey approach [5], [6], and to attain the research objectives, the investigator conducted a literature review to collect relevant information and then used the information, as well as the research framework, to develop the Questionnaire on Junior High School Students' Extracurricular Reading Attitude and 
Learning-associated Well-being. This is the research tool of the study.

To objectively analyze the extracurricular reading attitude and the learning-associated well-being of junior high school students in Changhua County, the investigator conducted a literature review and the gathered information was used as the theoretical base of the research and for developing the first draft of the questionnaire. The questionnaire contains three parts. The first part is for collecting personal background information, including gender, age, the socioeconomic status of the family, location of the school, weekly extracurricular reading time, encouragement to read from teachers, and reading environment at home these seven factors. The second part is about students' extracurricular reading attitude, which covers three areas: their reading preference, reading achievement and challenges, and reading behavior (26 questions). The third part is about the learning-associated well-being and can be divided into satisfaction for life, self-approval, physical and mental health, and harmonious interpersonal relationship these five areas (30 questions), seeing Table II.

TABLE II: JUNIOR HIGH SCHOOL STUDENTS' EXTRACURRICULAR READING ATTITUDE AND LEARNING-ASSOCIATED WELL-BEING

\begin{tabular}{|c|c|c|c|}
\hline & Factors & $\begin{array}{c}\text { Number of } \\
\text { questions }\end{array}$ & Subtotal \\
\hline $\begin{array}{l}\text { Reading } \\
\text { attitude }\end{array}$ & $\begin{array}{c}\text { Reading preference } \\
\text { Reading } \\
\text { achievement and } \\
\text { challenges } \\
\text { Reading behavior }\end{array}$ & $\begin{array}{l}8 \\
8 \\
8\end{array}$ & 24 \\
\hline $\begin{array}{c}\text { Learning-asso } \\
\text { ciated } \\
\text { well-being }\end{array}$ & $\begin{array}{c}\text { Satisfaction with life } \\
\text { Self-approval } \\
\text { Positive affection } \\
\text { Physical and mental } \\
\text { health } \\
\text { Harmonious } \\
\text { interpersonal } \\
\text { relationship } \\
\end{array}$ & $\begin{array}{l}8 \\
7 \\
7 \\
7\end{array}$ & 37 \\
\hline & Total & & 61 \\
\hline
\end{tabular}

\section{Research Implementation}

\section{1) Pilot stage}

At the completion of the first draft of the questionnaire, experts and scholars were invited to review the content and a pilot questionnaire was created for testing the appropriateness and practicability of the questionnaire. Three junior high schools were randomly sampled from the study population and their students were asked to fill out the pilot questionnaire. These questionnaires were retrieved. Question item analysis, factor analysis, and reliability analysis were conducted, and question items that were invalid or with little or no relevancy were eliminated. The remaining question items were included in the formal questionnaire.

\section{2) Formal questionnaire survey implementation}

Once the formal questionnaire was created, a stratified random sampling was conducted with public junior high school students in Changhua County as the study population. Before mailing the questionnaires to the sampled schools, the investigator first phoned the teacher of each junior high school responsible for the questionnaire survey to request the teacher to give assistance on the distribution and retrieval of the questionnaire as well as to mail the retrieved questionnaires back to the investigator. The questionnaires were mailed to each sampled school on April 14, 2014, and two weeks after, the investigator phoned those schools that had not yet returned the questionnaires. A total of 900 questionnaires were distributed and 900 questionnaires were retrieved (retrieval rate $=100 \%$ ). Among them, 815 questionnaires were valid and 85 invalid, making the valid rate or retrieved questionnaire $90.6 \%$.

\section{RESEARCH SCOPE AND LIMITATIONS}

The study subjects were public junior high school students in Changhua County in 2013. The study was aimed to explore the association between junior high school students' extracurricular reading attitude and learning-associated well-being. There are many variables affecting junior high school students' extracurricular reading attitude and learning-associated well-being, but the study only selected some of these variables, making the research less comprehensive. The scope and limitations of the study are presented below.

\section{A. Research Subjects}

The study subjects were public junior high school grade 7 , 8, and 9 students in Changhua County in 2013, but students from special education classes were excluded in this study. A total of 44,941 students were surveyed.

\section{B. Targeted Research Region}

The study subjects were limited to Changhua County students only, and further investigation is required to examine if the present study finding can be applied on students from a different education system or from other regions in Taiwan.

\section{Research Tools}

The research tool of this study is "The Questionnaire on Junior High School Students' Extracurricular Reading Attitude and Learning-associated well-being". The questionnaire was revised and developed based on relevant literature. Expert validity was established. As a result, the study results can be applied within this scope only .

\section{Research Variables}

There are many factors influencing students' reading attitude and learning-associated well-being. The investigators chose the following eight variables to investigate, and they are gender, grade year, contest participation experience, school location, parents' socioeconomic status, weekly extracurricular reading time, encouragement to read from teachers, and reading environment at home.

\section{DATA ANALYSIS AND DiscusSiON}

Data collected from the Questionnaire on Junior High School Students' Extracurricular Reading Attitude and Learning-associated Well-being were statistically analyzed and discussed based on the research objectives and hypotheses.

\section{A. Analysis of Profiles of Research Subjects Analysis of Students' Personal Background Variables}


The analysis of students background variables described in Table III.

\begin{tabular}{|c|c|c|c|}
\hline $\begin{array}{l}\text { Students' personal } \\
\text { background } \\
\text { information }\end{array}$ & Options & $\begin{array}{l}\text { Number of } \\
\text { people }\end{array}$ & $\begin{array}{c}\text { Percentag } \\
\text { e }\end{array}$ \\
\hline \multirow{2}{*}{ Gender } & Male & 365 & 44.8 \\
\hline & Female & 450 & 55.2 \\
\hline \multirow{3}{*}{ Grade year } & Grade 7 & 312 & 38.3 \\
\hline & Grade 8 & 257 & 31.5 \\
\hline & Grade 9 & 246 & 30.2 \\
\hline \multirow[b]{3}{*}{ School location } & Township & 385 & 47.2 \\
\hline & Town & 282 & 34.6 \\
\hline & $\begin{array}{l}\text { County-ad } \\
\text { ministered } \\
\text { city }\end{array}$ & 148 & 18.2 \\
\hline \multirow{2}{*}{$\begin{array}{c}\text { Contest participating } \\
\text { experience }\end{array}$} & Yes & 342 & 42.0 \\
\hline & No & 473 & 58.0 \\
\hline \multirow{3}{*}{$\begin{array}{l}\text { Weekly extracurricular } \\
\text { reading }\end{array}$} & 1 to 2 days & 416 & 51.0 \\
\hline & $\geq 3$ days & 153 & 18.8 \\
\hline & $\begin{array}{l}\text { No morning } \\
\text { reading }\end{array}$ & 246 & 30.2 \\
\hline \multirow{2}{*}{$\begin{array}{l}\text { Classroom reading } \\
\text { environment }\end{array}$} & $\begin{array}{c}\text { Planned } \\
\text { area }\end{array}$ & 432 & 53.0 \\
\hline & $\begin{array}{c}\text { No planned } \\
\text { area }\end{array}$ & 383 & 47.0 \\
\hline \multirow{2}{*}{$\begin{array}{l}\text { Reading environment } \\
\text { at home }\end{array}$} & Suitable & 728 & 89.3 \\
\hline & No suitable & 87 & 10.7 \\
\hline \multirow{3}{*}{$\begin{array}{l}\text { Family socioeconomic } \\
\text { status }\end{array}$} & High & 243 & 29.8 \\
\hline & Middle & 332 & 40.7 \\
\hline & Low & 240 & 29.4 \\
\hline
\end{tabular}

$N=815$

\section{B. Analysis of the Present Condition of Junior High School Students' Extracurricular Reading Attitude and Learning-Associated Well-Being}

The key objective of this section is to explore the present condition of junior high school students' extracurricular reading attitude and learning-associated well-being.

1) Analysis of the present condition of junior high school students' extracurricular reading attitude

For junior high school students' extracurricular reading attitude, the average overall score was 3.53, and therefore, the extracurricular reading attitude of junior high school students in Changhua County was close to "satisfied", seeing Table IV.

TABLE IV: SUMMARY OF THE PRESENT CONDITION OF ASPECTS OF EXTRACURRICULAR READING ATTITUDE OF JUNIOR HIGH SCHOOL STUDENTS

\begin{tabular}{lccccc}
\hline \multicolumn{1}{c}{ Factors } & $\begin{array}{c}\text { No.of } \\
\text { questions }\end{array}$ & $\mathrm{M}$ & SD & Sequence & Satisfaction \\
\hline $\begin{array}{l}\text { Reading } \\
\text { preference }\end{array}$ & 6 & 3.68 & .82 & 1 & Satisfied \\
\hline $\begin{array}{l}\text { Reading } \\
\text { achievement } \\
\text { and } \\
\text { challenges }\end{array}$ & 4 & 3.57 & .80 & 2 & Satisfied \\
\hline $\begin{array}{l}\text { Reading } \\
\text { behavior }\end{array}$ & 6 & 3.36 & .94 & 3 & Neutral \\
\hline Overall & 16 & 3.53 & .75 & & \\
\hline$N=815$ & & & & &
\end{tabular}

$N=815$

2) Analysis of the present condition of junior high school students' learning-associated well-being

For junior high school students' learning-associated well-being, the average overall score was 3.43, suggesting that the learning-associated well-being of junior high school students in Changhua County was close to "neutral", seeing Table V.

TABLE V: SUMMARY OF THE PRESENT CONDITION OF ASPECTS OF LEARNING-ASSOCIATED WELL-BEING OF JUNIOR HIGH SCHOOL STUDENTS

\begin{tabular}{cccccc}
\hline Factors & $\begin{array}{c}\text { Number } \\
\text { of questions }\end{array}$ & M & SD & Rank & Satisfaction \\
\hline $\begin{array}{c}\text { Satisfaction } \\
\text { with life }\end{array}$ & 5 & 3.40 & .78 & 3 & Neutral \\
\hline Self-approval & 5 & 3.39 & .81 & 4 & Neutral \\
\hline $\begin{array}{c}\text { Positive } \\
\text { affection }\end{array}$ & 5 & 3.55 & .80 & 1 & Satisfied \\
\hline $\begin{array}{c}\text { Physical and } \\
\text { mental health }\end{array}$ & 5 & 3.51 & .79 & 2 & Satisfied \\
\hline $\begin{array}{c}\text { Harmonious } \\
\text { interpersonal } \\
\text { relationship }\end{array}$ & 7 & 3.33 & .82 & 5 & Neutral \\
\hline Overall & 27 & 3.43 & .68 & & \\
\hline$N=815$ & & & & & \\
\hline
\end{tabular}

\section{Analysis of Effects of Various Background Variables on Junior High School Students' Extracurricular Reading Attitude}

\section{1) Analysis of the effect of gender on junior high school students' extracurricular reading attitude}

Overall, gender was found to have a significant effect on junior high school students' extracurricular reading attitude $(t=-5.156, p<.001)$. In other words, there was a significant difference between male and female junior high school students on their extracurricular reading attitude. The result showed that female students have a higher score than male students do, and therefore, female students' extracurricular reading attitude was better than male students'.

2) Analysis of the effect of grade year on junior high school students' extracurricular reading attitude

Overall, grade year was found to have no significant effect on junior high school students' extracurricular reading attitude $(t=2.170, p>.05)$. This finding suggested a lack of significant difference among junior high school students of different grades on their extracurricular reading attitude.

3) Analysis of the effect of family socioeconomic status on junior high school students' extracurricular reading attitude

Overall, family socioeconomic status was found to have a significant effect on junior high school students' extracurricular reading attitude $(F=8.406, p<.001)$. This finding suggested that there was a significant difference in junior high school students with different family socioeconomic status on their extracurricular reading attitude. Results from Scheffé's method showed that junior high school students from a family with a higher socioeconomic status $(M=3.69)$ had a better overall extracurricular reading attitude than students from a family with a middle socioeconomic status $(M=3.50)$ and students from a family with a low socioeconomic status $(M=3.42)$.

4) Analysis of the effect of contest participating experiment on junior high school students' extracurricular reading attitude

Junior high school students' contest participating experience was found to have a significant effect on their 
overall extracurricular reading attitude $(t=7.870, p<.001)$. In other words, junior high school students' extracurricular reading attitude differed depending on their contest participating experience. In fact, junior high school students with contest participating experience were found to have a better extracurricular reading attitude than those without any contest participating experience.

5) Analysis of the effect of school location on junior high school students' extracurricular reading attitude

Overall, school location was found to have a significant effect on junior high school students' extracurricular reading attitude $(F=4.690, p<.01)$. In other words, a significant difference existed among junior high school students on their extracurricular reading attitude because of their school location.

6) Analysis of the effect of weekly extracurricular reading time on junior high school students'

extracurricular reading attitude

Overall, weekly extracurricular reading time was found to have a significant effect on junior high school students' extracurricular reading attitude $(F=19.275, p<.001)$. In other words, junior high school students' extracurricular reading attitude differed depending on their weekly extracurricular reading time.

7) Analysis of the effect of encouragement to read from teachers on junior high school students' extracurricular reading attitude

Overall, encouragement to read from teachers was found to have no significant effect on junior high school students' extracurricular reading attitude $(t=-5.156, p>.05)$. In other words, junior high school students' extracurricular reading attitude was not affected by whether they receive encouragement from teachers on reading or not.

8) Analysis of the effect of reading environment at home on junior high school students' extracurricular reading attitude

Junior high school students' reading environment at home was found to have a significant effect on their overall extracurricular reading attitude $(t=4.701, p<.001)$. In other words, junior high school students' extracurricular reading attitude differed depending on their home reading environment. In fact, junior high school students with a good reading environment at home were found to have a better extracurricular reading attitude than those without a good reading environment at home.

\section{Analysis of Effects of Various Background Variables on Junior High School Students' Learning-Associated Well-Being}

\section{1) Analysis of the effect of gender on junior high school} students' learning-associated well-being

Overall, gender was found to have a significant effect on junior high school students' learning-associated well-being $(t=-2.415, p<.05)$. It suggested that there is a significant difference between male and female junior high school students in terms of their learning-associated well-being. More specifically, female students were found to have a higher score than male students do, meaning that female students had better learning-associated well-being than male students do.

2) Analysis of the effect of grade year on junior high school students' learning-associated well-being

Overall, grade year was found to have a significant effect on junior high school students' learning-associated well-being $(F=5.023, p<.05)$. In other words, there was a significant difference in junior high school students of different grade years on their learning-associated well-being. Results from Scheffé's method suggested that junior high school grade 7 students $(M=3.49)$ had better learning-associated well-being than grade 8 students $(M=3.32)$ do.

3) Analysis of the effect of family socioeconomic status on junior high school students' learning-associated well-being

Overall, family socioeconomic status was found to have no significant effect on junior high school students' learning-associated well-being $(F=2.207, p>.05)$. In other words, junior high school students' learning-associated well-being did not differ by their family socioeconomic status.

4) Analysis of the effect of contest participating experience on junior high school students'

learning-associated well-being

Junior high school students' contest participating experience was found to have a significant effect on their overall learning-associated well-being $(t=5.672, p<.001)$. In other words, junior high school students' learning-associated well-being differed depending on their contest participating experience. More specifically, junior high school students with contest participating experience were found to have better learning-associated well-being than those without any contest participating experience.

5) Analysis of the effect of school location on junior high school students' learning-associated well-being

Overall, school location was found to have a significant effect on junior high school students' learning-associated well-being $(F=5.825, p<.01)$. In other words, a significant difference existed among junior high school students on their learning-associated well-being because of their school location.

6) Analysis of the effect of weekly extracurricular reading time on junior high school students'

learning-associated well-being

Overall, weekly extracurricular reading time was found to have a significant effect on junior high school students' learning-associated well-being $(F=10.672, p<.001)$. In other words, there was a significant difference among junior high school students on their learning-associated well-being because of their weekly extracurricular reading time.

7) Analysis of the effect of encourage to read from teachers on junior high school students'

learning-associated well-being

Overall, encouragement to read from teachers was found to have no significant effect on junior high school students' learning-associated well-being $(t=1.000, p>.05)$. In other words, junior high school students' learning-associated 
well-being was not affected by whether or not they are encouraged to read by teachers.

\section{E. Correlation between Junior High School Students' Extracurricular Reading Attitude and Their Learning-Associated Well-Being}

\section{1) Various aspects of reading attitude on overall learning-associated well-being}

Reading behavior $(\gamma=.573)$, reading achievement and challenges $(\gamma=.569)$, and reading preference $(\gamma=.559)$ these three aspects (listed in descending order) of reading attitude of junior high school students were found to be significantly correlated with the overall learning-associated well-being, and they all had $p<.001$, suggesting a medium level of correlation.

\section{2) Overall reading attitude on overall \\ learning-associated well-being}

For junior high school students' overall extracurricular reading attitude and overall learning-associated well-being, there was a correction coefficient of 0.645 , with a significant level $p<0.001$. The value suggested a high level of correlation Therefore, junior high school students with a more positive extracurricular reading attitude may have better learning-associated well-being.

\section{CONCLUSIONS AND SUGGESTIONS}

\section{A. Conclusions}

\section{1) Junior high school students in Changhua county} showed a more positive attitude on "reading preference" of extracurricular reading attitude.

In the study, junior high school students' extracurricular reading attitude comprised three variables: reading preference, reading achievement and challenges, and reading behavior. The study results suggested that the extracurricular reading attitude of junior high school students in Changhua County was average in general; that is, these students were found to consider reading interesting, enjoy reading a variety type of books, and feel reading extracurricular reading materials pleasant. Among the three variables of reading attitude, junior high school students in Changhua County showed a more passive attitude on "reading behavior", suggesting that they are more passive in reading extracurricular reading materials, require teachers to prompt them to do so, and do not borrow books from the library or buy books from bookstores. They need to be more initiative in reading

2) For learning-associated well-being, junior high school students in Changhua county scored the highest for positive affection and physical and mental health

In the study, junior high school students' learning-associated well-being comprised five variables: satisfaction with life, self-approval, positive affection, physical and mental health, and harmonious interpersonal relationship. The results showed that among all variables of learning-associated well-being, junior high students scored the highest on positive affection, followed by physical and mental health. This means that the students considered themselves capable of handling problems with positive affection instead of negative affection, and at school, they rarely worry and experience little anxiety. The result also showed that the students believe that success comes from hard work and they have been very energetic in learning. The score of harmonious interpersonal relationship is the lowest, suggesting that these students are less satisfied with their interaction with teachers and peers at school. As a result, it is an issue cared the most by junior high school students.

Female students studying at schools in town that schedule morning reading at least three times a week, coming from a family with a higher socio-economic status and providing a good reading environment, and having language contest participating experience showed a more active reading attitude.

Grade 7 female students studying at schools in town that schedule morning reading at least three times a week, coming from a family providing a good reading environment at home, and having language contest participating experience showed better learning-associated well-being.

Junior high school students with a better extracurricular material reading attitude were found to have better learning-associated well-being.

The study found a positive correlation between the overall extracurricular reading attitude and the learning-associated well-being in junior high school students in Changhua County. This finding suggested that the learning-associated well-being in junior high school students in Changhua County is affected by their extracurricular reading attitude; students with a more active reading attitude also have better learning-associated well-being.

\section{B. Suggestions}

According to results from analyzing the questionnaire survey data, the investigator offers the following suggestions to educational administrative authorities, schools, teachers, and researchers interested in carrying out relating research in the future.

\section{1) For educational administrative authorities}

1) When designing large-scale reading promoting activities, make students the focus of these activities.

2) For reading related software, hardware, and activities used in Changhua County, the teachers should first learn about these materials.

3) It is recommended to open reading courses that are not focused on academic work and to assign teachers to be fully responsible for teaching these reading courses.

2) For schools

1) Different school departments should work together to offer students sufficient morning reading time.

2) School libraries should include digital reading materials to increase students' use rate.

\section{3) For teachers}

1) To promote extracurricular reading, a reading club can be set up at each class.

2) To encourage male students to read, teachers can provide more pluralistic reading materials.

3) For reading education, teachers should work on enhancing students' reading comprehensive competence.

4) Teachers can provide students' parents with reading 
related information to help them create a good reading environment at home.

5) Teachers should participate in reading education related seminars and workshops more frequently to be more competent in handling individual differences among students so students' reading attitude and learning-associated well-being can be improved.

\section{4) For future research}

The study used the questionnaire survey approach, and the following suggestions are provided for researchers interested in conducting relating studies in the future.

\section{5) For research methodology}

The study analyzed the data quantified from the questionnaire survey results and the conclusions were drawn based on the analysis results. One concern here is that the conclusion on students' extracurricular reading attitude, their learning-associated well-being, and differences among students were solely established based on data acquired from the questionnaire survey. Secondly, the investigator did not use other methods to validate the finding, and therefore, the collected data may be biased by factors such as subjects' emotion, pressure, self-defense, and social expectation. Therefore, other researchers can conduct a qualitative study to complement shortcomings of quantitative studies to gain better insight into the current condition and causes of the differences.

\section{6) For research subjects}

Because of the limited man power, resources, and time, study subjects were limited to junior high school students in Changhua County. As a result, the study finding can be applied on junior high school students in Changhua County only. A suggestion for researchers interested in this domain is to expand the study subjects to students at other cities and counties to explore the regional effect on extracurricular reading attitude and learning-associated well-being.

\section{REFERENCES}

[1] X. Q. Zeng and X. P. Han, Reading Research Abroad, Zhengzhou, China: Da Xiang Publishing House, 2002.

[2] H. W. Ko, "How to teach reading competence: Cultivating super young readers," Common Wealth Magazine, 2009.
[3] R. Veenhoven, "Is happiness a trait? Test of the theory that a better society does not make people any happier," Social Indicators Research, vol. 32, pp. 101-160, 1994.

[4] D. M. Buss, "The evolution of happiness," American Psychologist, vol. $15,2000$.

[5] Q. Uchida and Y. M. Chen, Using SPSS for Opinion Polling Statistical Analysis, Taipei: Tingmao Publish Company, 2007.

[6] C. Y. Ho and C. C. Chien, "Qualities required for 21th century education," Parenting, Family Lifestyle, 2012, pp. 12-17.

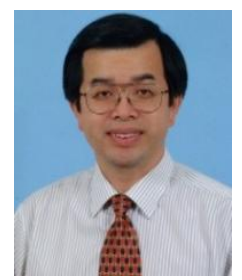

Chin-Chang Wu received the M.S. in education from National Changhua University of Education, Taiwan, R.O.C. and the Ph.D in industrial education and technology from National Changhua University of Education in 2005. He has been a school principal in Dong- Shing Elementary School, Taiwan, R.O.C. and dealt with administrative affairs of the school. His research interests include leading, technology, and vocational education.

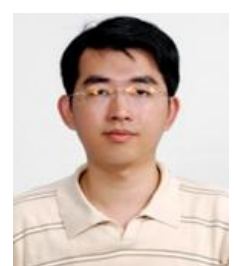

Ming-Shang Su received the M.S. degree at the Department of Industrial Educationand Technology from National Changhua University of Education in 2010, and currently he is a doctoral student at the Department of Industrial Education from National Changhua University, Taiwan, R.O.C. Since August 2013, he has been a section chief of search in Changhua county Hsiushui Junior High School in Taiwan, R.O.C. Since August 2005, he has taught courses in math in the same school.

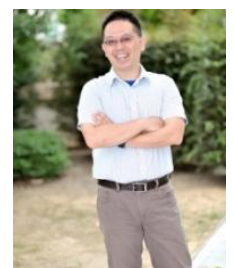

Ta-Chun Chang received the M.S. degree at the Department of Industrial Education from National Changhua University in 2001, and currently he is a doctoral student at the Department of Industrial Education from National Changhua University, Taiwan, R.O.C. Since August 2014, he has been a director of student affairs in Taichung Municipal Lishin Junior High School in Taiwan, R.O.C. Since August 2013, he has taught courses in mathematics study in the same school.

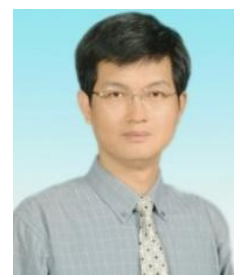

Chin-Wen Liao received both the M.S. and Ph.D. degrees in industrial education from National Taiwan Normal University, Taiwan, R.O.C. in 1994 and 2002, respectively. Since August 2011, he has been a professor in the Department of Industrial Education and Technology at National Changhua University of Education (NCUE) in Taiwan, R.O.C. He teaches courses in technology and vocational education, energy education, course and teaching, organizational learning. His research interests include technology and vocational education, teacher education, energy education of technology, and learning organization. 